\title{
ALLELOPATHIC POTENTIAL AND PHYTOCHEMICAL SCREENING OF FOUR MEDICINAL PLANTS OF NEPAL
}

\author{
Swasti Sharma and Anjana Devkota* \\ *Central Department of Botany, Tribhuban University, Kathmandu.
}

\begin{abstract}
The laboratory tests were conducted to evaluate the allelopathic potential and phytochemical study of the four selected medicinal plants Ageratum conyzoides, Eclipta prostrata, Cannabis sativa and Woodfordia fructicosa. The aqueous extract bioassay of the plants with stem and root were conducted on the two test seeds Triticum aestivum (wheat) and Pisum sativum (pea) by filter paper method. Germination, seedling growth and biomass production were observed under the allelopathic study whereas under phytochemical study qualitative or presence or absence and quantitative or crude amount of the phytochemicals present were also estimated. For the allelopathic studies the germination and seedling growth of wheat and pea test species under the different concentrations $2 \%, 4 \%$, $6 \%, 8 \%$ and $10 \%$ of the stem and root extracts of the plants under study were carried out. Increased concentration of the aqueous extracts of the plants increased the inhibitory rate or decreased the germination and seedling growth.Species sensitivity varied with the test seeds and alkaloid, flavonoid, saponin, tannin, phenol, glycoside and essential oil were the phytochemicals present in the plant extracts.
\end{abstract}

Keywords: Allelopathy; Phytochemical study; Inhibitory effect.

\section{INTRODUCTION}

Medicine from plant sources have been in use in Homeopathy, Ayurvedic, Allopathy and in traditional medicine since time immemorial. Medicinal plants plays a significant role among the traditional and modern systems. In developing countries, $80 \%$ of the population still use traditional folk medicines obtained from plants 1 . The medicinal values of the plants lie in the bioactive phytochemical constituents that produce physiological effects on the human body. The most important of these bioactive constituents of plants are alkaloids, tannins, flavonoids and some other phenolic compounds 2 . The effect of these chemicals are not limited to animal and human body alone but also on other plants. Many plants including medicinal plants were reported to interact chemically with other plant species. Such chemical interaction is known as allelopathy.

Allelochemicals are low molecular weight compounds excreted from plants during the process of secondary metabolism ${ }^{3}$. They are present in all parts of the plant tissues including leaves, stem, roots, rhizomes, flowers, fruits, seeds and even in pollen grains released from the plants by volatilization, leaching, excudation and decomposition from plant residues ${ }^{4}$.Their activity varies with temperature, photoperiod, water and soils, during natural processes with its initial concentration, compound structure and mixed degree during functional processes with plant accessions, tissues and maturity within species 5 . Allelopathic potential of some selected species had been studied by earlier workers6-8. The present study seems more significant as we can display the phytochemicals present in the plants for isolation and further phytochemical analysis as well as for the use of local community.

\section{MATERIALS AND METHODS}

\section{Collection of plant materials}

Stem and root of four medicinal plants under study were collected from Kirtipur and Chitwan districts of Nepal. The plants under study: Ageratum conyzoides and Cannabis sativa were collected from Kirtipur, Kathmandu and Woodfordia fructicosa and Eclipta prostrata were collected from Kasara, Chitwan. Then these samples were air dried, finely powdered in grinder and then kept in zipper plastic bags for further study.

\section{Test plants}

Test seeds: Pisum sativum (pea) and Triticum aestivum (wheat) were taken from Botany Division, NARC (National Agriculture Research Center), Khumaltar, Lalitpur. These seeds were selected as they germinate easily, easy to handle, with high fecundity rate, showed pronounced effects after the application of aqueous extracts.

\section{AllelopathicPotential}

Ten gm powdered stem and root extracts of each plants were mixed with $100 \mathrm{ml}$ distilled water and kept in

Author for Correspondence: Anjana Devkota, Central Department of Botany, Tribhuban University, Kathmandu, Nepal. E-mail: devkotaa@gmail.com. 
dark at the room temperature for $24 \mathrm{~h}$. Aqueous extract was obtained as the filtrate of the mixture. Filtration was done by double layered muslin cloth followed by Whatmann No 1 filter paper. Final volume was adjusted to $100 \mathrm{ml}$; this gave $10 \%$ aqueous extract. The extract was considered as stock solution and a series of solution with different strengths (2, 4, 6 and $8 \%)$ were prepared by dilution. Fifteen uniform and surface sterilized seeds washed with $2 \%$ sodium hypochlorite for 15 minutes were kept for germination in sterilized glass petri-dishes. Petri dishes were lined double with blotting papers and moistened with $10 \mathrm{ml}$ of different concentrations of aqueous extracts. Three control sets for wheat and pea seeds each taking $10 \mathrm{ml}$ distilled water as the solution in each petri dishes were taken. The petri dishes were kept under the laboratory condition (room temperature $25^{\circ} \mathrm{C}$ ) with the diffused sunlight during the daytime for 7 days. After one week, number of germinated seeds were counted and the root and shoot length were measured. This experiment was repeated twice and data were pooled together before analysis.

\section{Phytochemical screening methods}

Tests on aqueous extract of powdered specimens using standard procedure were carried out to identify the constituents as described by previous authors9-11.

\section{RESULTS}

\section{Allelopathy}

Effects of aqueous extracts of four medicinal plants on the seed germination of wheat and pea

All studied medicinal plants had significant effect on seed germination of wheat and pea ( Tables 1 and 2). The inhibitory effect on germination was increased with increasing concentrations of the extracts. Maximum $100 \%$ germination of wheat seeds was in $2 \% \mathrm{~W}$. fruticosa stem extracts wheras in pea seeds maximum $97.8 \%$ germination was seen in $2 \%$ concentration of the $A$. conyzoides and $C$. sativa root extracts. Inhibitions on germination of both the tested seeds were higher at higher concentration of the E. prostrata plant extracts.

\section{DISCUSSION}

Allelopathic effect of selected medicinal plants can be attributed to the presence of phenolic compounds such as flavonoids, tannins and phenols. The effect may be due to synergistic effect rather than single constituent. This phenolic compounds interfere with the activities of respiratory enzymes in seed germination thereby causing inhibitory effect on its germination 12 alteration in the activities of the growth hormone Giberellic acid (responsible for stimulation of seed germination) 13 . Among the four studied plant species, Eclipta prostrata and Ageratum conyzoides belonging to family Asteraceae were found to show strong allelopathic effect. E. prostrata plant showed maximum allelopathic effect on wheat plant. C. sativa and then A. conyzoides showed maximum allelopathic effect on the pea plant. Inhibitory effect was found higher in stem extracts of the plants understudy than the root extracts. The phenolic compounds present in Ageratum conyzoides may be responsible for the strong allelopathic activity of the plant especially on pea seeds and also the least biomass production by the stem extract. Ageratum conyzoides was the plant with highest allelopathic potential in the comparative study for ten medicinal plants ${ }^{14}$. In $E$. prostrata there was significant difference within the different concentrations of the plant extracts but difference was low from that of control which may be due to maximum inhibitory effect which resulted from the combined effect of the allelochemicals.

Phenolic compounds such as flavonoids, tannins and phenols were reported as the most common and widely distributed water soluble alleochemicals, they are released to soil by volatilization process and mix easily in the soil nutrients which may be the reason for their higher allelopathic activity ${ }^{3}$. The presence of phenols, saponin and essential oil in highest amount in C. sativa and overall combined effect of the phytochemicals present in the plant extracts of Eclipta prostrata and Cannabis sativa must be responsible for their strong allelopathic activity. In Woodfordia fructicosa highest amount of alkaloids and flavonoids were present even though inhibitory effect was seen at wheat seeds stimulatory effect was also seen at the pea test seeds. Flavonoids present in highest amount in $W$. fructicosa did not show inhibitory effect rather stimulatory effect and maximum biomass production, germination and seedling growth was shown by the combined effect of all the phytochemicals present in pea test seeds . Maximum wheat biomass was produced in $C$. sativa plant extracts.

Wheat seeds were found more sensitive to E. prostrata and $W$. fructicosa plant extracts. Pea seeds were found more sensitive to $A$. conyzoides and $C$. sativa plant extracts. Root length was the best indicator of allelopathic effects of plant extracts because radicle growth has been reported to be more sensitive to phytotoxic compounds than plumule growth. Furthermore, the permeability of allelochemicals to root tissue was reported to be greater than that to shoot tissue 15 . This might be due to direct contact of root with the extract and subsequently with inhibitory chemicals as described earlier with various crops and weeds by16-17. 6Maharjan et al. (2007) also the strong inhibitory effect by the aqueous plant extract of Parthenium hysterophorus on root elongation of seedlings in cereals and shoot elongation in crucifers and wild Asteraceae also reported by previous researcher 6 .

The phenolic compounds are one of the largest and most ubiquitous groups of plant metabolites 18 . They possess biological properties such as antiaging, anticarcinogen, antiinflammation, antiatherosclerosis, cardiovascular protection and improvement of endothelial function, as well as inhibition of angiogenesis and cell proliferation activities ${ }^{19}$. Alkaloids are the largest groups of phytochemicals in plants have amazing effects on humans and this has led to the development of powerful pain killer medications.Tannins showed anti-inflammatory and anti-bacterial properties. Earlier author 20 reviewed the biological activities of tannins and observed that tannins have anticancer activity and can be used in cancer prevention. The diuretic and antibacterial 
Table 1: Effect of plants aqueous extracts on germination of wheat seeds. (Mean Germination \pm Standard Deviation) $(n=60)$.

\begin{tabular}{llllllll}
\hline \multirow{2}{*}{ Species name } & & \multicolumn{7}{c}{ Germination\% } \\
\cline { 2 - 7 } & Plant part & Control(0\%) & $\mathbf{2 \%}$ & $\mathbf{4 \%}$ & $\mathbf{6 \%}$ & $\mathbf{8 \%}$ & $\mathbf{1 0 \%}$ \\
\hline A. conyzoides L. & Stem & $97.8 \pm 0.58$ & $97.8 \pm 0.58$ & $97.8 \pm 0.58$ & $91.1 \pm 0.58$ & $91.1 \pm 0.58$ & $88.9 \pm 1.15$ \\
& Root & $97.8 \pm 0.58$ & $95.6 \pm 0.58$ & $93.3 \pm 0.58$ & $95.6 \pm 0.58$ & $88.9 \pm 1.15$ & $88.9 \pm 1.15$ \\
C.sativa L. & Stem & $97.8 \pm 0.58$ & $97.8 \pm 0.58$ & $95.6 \pm 0.58$ & $86.7 \pm 1.00$ & $86.7 \pm 1.00$ & $84.5 \pm 0.58$ \\
& Root & $97.8 \pm 0.58$ & $95.6 \pm 0.58$ & $93.3 \pm 0.58$ & $84.4 \pm 2.08$ & $91.1 \pm 0.58$ & $82.2 \pm 1.15$ \\
E. prostrata L. & Stem & $97.8 \pm 0.58$ & $93.3 \pm 0.00$ & $86.7 \pm 1.00$ & $84.5 \pm 0.58$ & $82.2 \pm 1.15$ & $80 \pm 1.00$ \\
& Root & $97.8 \pm 0.58$ & $93.3 \pm 0.00$ & $86.7 \pm 0.00$ & $84.4 \pm 0.58$ & $82.2 \pm 1.15$ & $80 \pm 1.10$ \\
W. fructicosa Kurz. & Stem & $97.8 \pm 0.58$ & $100 \pm 0.0$ & $95.6 \pm 1.15$ & $84.5 \pm 0.58$ & $82.2 \pm 1.15$ & $80 \pm 1.00$
\end{tabular}

Table 2: Effect of plants aqueous extracts on germination of pea seeds. (Mean Germination \pm Standard Deviation) $(n=60)$.

\begin{tabular}{llllllll}
\hline \multirow{2}{*}{ Species name } & Plant & \multicolumn{7}{c}{ Germination \% } \\
\cline { 3 - 8 } & parts & Control (0\%) & $\mathbf{2} \%$ & $\mathbf{4} \%$ & $\mathbf{6 \%}$ & $\mathbf{8} \%$ & $\mathbf{1 0} \%$ \\
\hline A conyzoides L. & Stem & $97.8 \pm 0.58$ & $95.3 \pm 0.58$ & $93.3 \pm 1.00$ & $93.3 \pm 1.00$ & $93.3 \pm 1.00$ & $88.7 \pm 1.52$ \\
& Root & $97.8 \pm 0.58$ & $97.8 \pm 0.58$ & $91.1 \pm 0.58$ & $91.1 \pm 1.15$ & $91.1 \pm 1.15$ & $86.7 \pm 0.00$ \\
C. sativa L. & Stem & $97.8 \pm 0.58$ & $93.3 \pm 1.0$ & $93.3 \pm 1.0$ & $88.7 \pm 1.15$ & $86.7 \pm 1.0$ & $88.7 \pm 1.0$ \\
& Root & $97.8 \pm 0.58$ & $97.8 \pm 0.58$ & $93.3 \pm 1.0$ & $91.1 \pm 1.52$ & $88.7 \pm 0.58$ & $88.7 \pm 1.0$ \\
E. prostrata L. & Stem & $97.8 \pm 0.58$ & $93.3 \pm 1.00$ & $86.7 \pm 0.00$ & $91.1 \pm 1.15$ & $86.7 \pm 1.0$ & $91.1 \pm 1.15$ \\
& Root & $97.8 \pm 0.58$ & $95.3 \pm 0.58$ & $93.3 \pm 0.00$ & $93.3 \pm 1.00$ & $84.5 \pm 0.58$ & $84.5 \pm 0.58$ \\
W. fructicosa Kurz. & Stem & $97.8 \pm 0.58$ & $95.3 \pm 0.58$ & $91.1 \pm 0.58$ & $91.1 \pm 1.15$ & $86.7 \pm 1.00$ & $86.7 \pm 1.00$ \\
& Root & $97.8 \pm 0.58$ & $93.3 \pm 1.00$ & $88.7 \pm 0.58$ & $91.3 \pm 0.58$ & $91.3 \pm 1.15$ & $91.3 \pm 1.15$ \\
\hline
\end{tabular}

Effects of aqueous extracts of four medicinal plants on the seedling growth of wheat

There was significant difference $(\mathrm{p}<0.001)$ between the treatments in plumule and radicle length of wheat seeds (Tables 3 and 4). Maximum plumule inhibition in wheat was shown by $10 \%$ stem extract of $E$. prostrata whereas minimum by $4 \%$ stem extract of $W$. fructicosa. Maximum radical inhibition was shown by $10 \%$ leaf extract of $E$. prostrata

Table 3: Effect of plant aqueous extracts on plumule length of wheat. For each parameter, significant difference between mean among the treatments are indicated by different letters (Duncan homogeneity test, $\dot{a}=\mathbf{0 . 0 5}$ ). $\mathrm{F}$ and $\mathrm{P}$ values were obtained by one way analysis of variance (ANOVA). $(\mathrm{n}=60)$.

\begin{tabular}{|c|c|c|c|c|c|c|c|c|c|}
\hline \multirow[b]{2}{*}{$\begin{array}{l}\text { Species } \\
\text { name }\end{array}$} & \multirow[b]{2}{*}{$\begin{array}{l}\text { Plant } \\
\text { parts }\end{array}$} & \multicolumn{6}{|c|}{ Plumule length $(\mathrm{cm})$ at different concentration } & \multirow[b]{2}{*}{ F-Value } & \multirow[b]{2}{*}{ P-Value } \\
\hline & & Control & $2 \%$ & $4 \%$ & $6 \%$ & $8 \%$ & $10 \%$ & & \\
\hline Ageratum & Stem & $13.68 \pm 1.3^{\mathrm{e}}$ & $11.06 \pm 3.42^{\mathrm{d}}$ & $10.01 \pm 2.47^{\mathrm{c}}$ & $10.87 \pm 2.0^{\mathrm{c}}$ & $8.25 \pm 2.90^{\mathrm{a}}$ & $9.51 \pm 2.14^{\mathrm{b}}$ & 43.355 & 0.000 \\
\hline conyzoides $L$. & Root & $13.68 \pm 1.3^{\mathrm{c}}$ & $11.37 \pm 1.82^{\mathrm{b}}$ & $10.03 \pm 2.15^{\mathrm{b}}$ & $8.89 \pm 2.31^{\mathrm{a}}$ & $9.80 \pm 1.03^{\mathrm{a}}$ & $9.57 \pm 1.22^{\mathrm{a}}$ & 6.714 & 0.000 \\
\hline Cannabis & Stem & $13.68 \pm 1.3^{\mathrm{d}}$ & $11.88 \pm 1.01^{\mathrm{c}}$ & $10.25 \pm 2.12^{\mathrm{b}}$ & $12.41 \pm 2.3^{\mathrm{c}}$ & $12.41 \pm 2.13^{\mathrm{c}}$ & $9.15 \pm 2.1^{\mathrm{a}}$ & 54.74 & 0.000 \\
\hline sativa $L$ & Root & $13.68 \pm 1.3^{\mathrm{d}}$ & $10.00 \pm 0.12^{\mathrm{bc}}$ & $11.61 \pm 2.2^{\mathrm{c}}$ & $11.11 \pm 1.8^{\mathrm{c}}$ & $9.34 \pm 2.94^{b}$ & $8.68 \pm 2.40^{\mathrm{a}}$ & 22.07 & 0.000 \\
\hline Eclipta & Stem & $13.68 \pm 1.3^{\mathrm{d}}$ & $3.09 \pm 0.98^{c}$ & $2.26 \pm 1.02^{\mathrm{c}}$ & $1.99 \pm 0.87^{b}$ & $1.89 \pm 0.87^{\mathrm{ab}}$ & $0.91 \pm 0.16^{\mathrm{a}}$ & 15.51 & 0.000 \\
\hline prostrata $L$. & Root & $13.68 \pm 1.3^{\mathrm{c}}$ & $2.78 \pm 0.85^{\mathrm{b}}$ & $2.03 \pm 1.02^{b}$ & $1.88 \pm 1.11^{\mathrm{a}}$ & $1.87 \pm 0.86^{\mathrm{a}}$ & $1.02 \pm 0.16^{\mathrm{a}}$ & 29.38 & 0.000 \\
\hline Woodfordia & Stem & $13.68 \pm 1.3^{\mathrm{d}}$ & $9.12 \pm 2.91^{\mathrm{c}}$ & $9.70 \pm 3.06^{\mathrm{c}}$ & $9.97 \pm 2.25^{\mathrm{c}}$ & $6.80 \pm 2.48^{\mathrm{a}}$ & $7.85 \pm 1.29^{b}$ & 26.89 & 0.000 \\
\hline \multicolumn{10}{|l|}{ Kurz. } \\
\hline \multicolumn{5}{|c|}{$\begin{array}{l}\text { activity of plant extracts containing flavonoids have } \\
\text { been documented } 9 \text {. The presence of saponins in plants } \\
\text { have been reported to be responsible for the tonic and } \\
\text { stimulating activities observed in Chinese and Japanese } \\
\text { medical herbs. The results obtained in this study thus } \\
\text { suggested that the identified phytochemical compounds } \\
\text { may be the bioactive constituents responsible for the } \\
\text { efficacy of the parts of the plants studied. }\end{array}$} & \multicolumn{5}{|c|}{$\begin{array}{l}\text { So the phytochemicals; phenolic compounds, alkaloids } \\
\text { and saponins present in the plants under study which } \\
\text { show different medicinal properties were responsible for } \\
\text { allelopathic activities of the plants. So, the presence of } \\
\text { allelopathic phytochemicals in the four medicinal plants } \\
\text { under study A. conyzoides, C.sativa, E. prostrata and } \\
W \text {. fructicosa were responsible for the inhibitory effect } \\
\text { of the plants extracts on seed germination and seedling } \\
\text { growth of these plants. }\end{array}$} \\
\hline
\end{tabular}


Table 4: Effect of plant aqueous extracts on radicle length of wheat. For each parameter, significant difference between mean among the treatments are indicated by different letters (Duncan homogeneity test, $\dot{a}=0.05$ ). $F$ and $P$ values were obtained by one way analysis of variance (ANOVA). $(n=60)$.

\begin{tabular}{|c|c|c|c|c|c|c|c|c|c|}
\hline \multirow[b]{2}{*}{ Species name } & \multirow[b]{2}{*}{$\begin{array}{l}\text { Plant } \\
\text { parts }\end{array}$} & \multicolumn{6}{|c|}{ Radicle length $(\mathrm{cm})$ at different concentration } & \multirow[b]{2}{*}{ F-Value } & \multirow[b]{2}{*}{ P-Value } \\
\hline & & Control & $12 \%$ & $4 \%$ & $6 \%$ & $8 \%$ & $10 \%$ & & \\
\hline Ageratum & Stem & $12.78 \pm 1.1^{\mathrm{c}}$ & $5.47 \pm 1.31^{\mathrm{a}}$ & $7.87 \pm 1.9^{b}$ & $5.33 \pm 1.24^{\mathrm{a}}$ & $5.73 \pm 1.97^{\mathrm{a}}$ & $5.18 \pm 1.05^{\mathrm{a}}$ & 7.320 & 0.000 \\
\hline conyzoides $L$. & Root & $12.78 \pm 1.1^{\mathrm{d}}$ & $8.36 \pm 1.21^{\mathrm{c}}$ & $7.05 \pm 1.2^{\mathrm{b}}$ & $7.13 \pm 2.21^{\mathrm{b}}$ & $6.95 \pm 1.32^{\mathrm{ab}}$ & $6.39 \pm 2.03^{\mathrm{a}}$ & 22.08 & 0.000 \\
\hline Cannabis. & Stem & $12.78 \pm 1.1^{\mathrm{c}}$ & $6.83 \pm 1.21^{\mathrm{ab}}$ & $7.00 \pm 2.31^{\mathrm{b}}$ & $7.29 \pm 1.34^{\mathrm{b}}$ & $7.45 \pm 1.10^{\mathrm{b}}$ & $6.63 \pm 2.14^{\mathrm{a}}$ & 3.595 & 0.004 \\
\hline sativa $L$ & Root & $12.78 \pm 1.1^{\mathrm{b}}$ & $6.40 \pm 2.61^{\mathrm{a}}$ & $6.97 \pm 1.46^{\mathrm{a}}$ & $7.07 \pm 1.87^{\mathrm{a}}$ & $6.72 \pm 2.36^{\mathrm{a}}$ & $6.67 \pm 1.50^{\mathrm{a}}$ & 2.185 & 0.057 \\
\hline Eclipta & Stem & $12.78 \pm 1.1^{\mathrm{d}}$ & $3.24 \pm 1.01^{\mathrm{c}}$ & $1.91 \pm 0.98^{\mathrm{ab}}$ & $2.09 \pm 1.21^{\mathrm{b}}$ & $2.22 \pm 1.10^{\mathrm{b}}$ & $1.05 \pm 0.98^{\mathrm{a}}$ & 37.146 & 0.000 \\
\hline prostrata $L$. & Root & $12.78 \pm 1.1^{\mathrm{d}}$ & $3.11 \pm 1.03^{\mathrm{c}}$ & $2.76 \pm 1.32^{\mathrm{bc}}$ & $2.35 \pm 1.63^{\mathrm{b}}$ & $1.90 \pm 0.98^{\mathrm{a}}$ & $1.94 \pm 0.68^{\mathrm{a}}$ & 16.797 & 0.000 \\
\hline Woodfordia & Stem & $12.78 \pm 1.1^{\mathrm{e}}$ & $11.57 \pm 4.40^{\mathrm{d}}$ & $9.79 \pm 2.70^{c}$ & $6.04 \pm 1.0^{\mathrm{b}}$ & $6.14 \pm 1.70^{\mathrm{b}}$ & $5.54 \pm 1.89^{\mathrm{a}}$ & 52.563 & 0.000 \\
\hline $\begin{array}{l}\text { fructicosa } \\
\text { Kurz. }\end{array}$ & Root & $12.78 \pm 1.1^{\mathrm{c}}$ & $6.40 \pm 2.61^{\mathrm{a}}$ & $6.97 \pm 3.46^{\mathrm{ab}}$ & $7.07 \pm 3.87^{b}$ & $6.72 \pm 4.36^{\mathrm{a}}$ & $6.67 \pm 4.5^{\mathrm{a}}$ & 19.355 & 0.000 \\
\hline
\end{tabular}

Effect of aqueous plant extracts of four medicinal plants on seedling growth of pea

ANOVA showed significant difference between the treatments in plumule length of pea except for the root aqueous extract of $A$. conyzoides ( $\mathrm{p}=0.502$ ) (Table 5).Maximum plumule inhibition of pea seeds was in $4 \%$ stem extract of $C$. sativa whereas minimum inhibition was shown by $4 \%$ root extract of $W$. fructicosa. Significant difference for the radicle length of pea plant between the treatments were seen except for $A$. conyzoides root $(\mathrm{p}=0.230)$, C. sativa stem $(\mathrm{p}=0.404)$ and root $(\mathrm{p}=0.180)$ and E. prostrata stem $(\mathrm{p}=0.81)$ extracts (Table 6).Maximum radicle inhibition was shown by $C$. sativa $10 \%$ stem extract whereas minimum inhibition was in $4 \%$ stem extract of $A$. conyzoides. Stimulatory effect was shown by the $W$. fructicosa and $E$. prostrata plant extracts on their radicle growth. Maximum stimulatory effect was seen on $2 \%$ stem extract of $W$. fructicosa $(266.77 \%)$.

Table 5: Effect of plant aqueous extracts on plumule length of pea. For each parameter, significant difference between mean among the treatments are indicated by different letters (Duncan homogeneity test, $\dot{a}=0.05$ ). $F$ and $P$ values were obtained by one way analysis of variance (ANOVA). $(n=60)$.

\begin{tabular}{|c|c|c|c|c|c|c|c|c|c|}
\hline \multirow[b]{2}{*}{ Species name } & \multirow[b]{2}{*}{ Plant parts } & \multicolumn{6}{|c|}{ Plumule length $(\mathrm{cm})$ at different concentration } & \multirow[b]{2}{*}{ F-Value } & \multirow[b]{2}{*}{ P-Value } \\
\hline & & Control & $2 \%$ & $4 \%$ & $6 \%$ & $8 \%$ & 10 & & \\
\hline Ageratum & Stem & $2.15 \pm 1.21^{\mathrm{c}}$ & $0.59 \pm 0.18^{\mathrm{a}}$ & $0.44 \pm 0.28^{\mathrm{a}}$ & $0.67 \pm 0.30^{\mathrm{ab}}$ & $0.55 \pm 0.30^{\mathrm{a}}$ & $0.80 \pm 0.31^{\mathrm{b}}$ & 4.602 & 0.000 \\
\hline conyzoides $L$. & Root & $2.15 \pm 1.21^{\mathrm{c}}$ & $0.86 \pm 0.19^{\mathrm{b}}$ & $0.88 \pm 0.43^{\mathrm{b}}$ & $0.79 \pm 0.25^{\mathrm{a}}$ & $0.72 \pm 0.39^{\mathrm{a}}$ & $0.73 \pm 0.35^{\mathrm{a}}$ & 0.870 & 0.502 \\
\hline Cannabis & Stem & $2.15 \pm 1.21^{\mathrm{c}}$ & $1.58 \pm 0.40^{\mathrm{b}}$ & $1.45 \pm 0.56^{\mathrm{b}}$ & $0.72 \pm 0.22^{\mathrm{a}}$ & $0.65 \pm 0.36^{\mathrm{a}}$ & $0.64 \pm 0.17^{\mathrm{a}}$ & 1.99 & 0.050 \\
\hline sativa $L$ & Root & $2.15 \pm 1.2^{\mathrm{d}}$ & $0.58 \pm 0.20^{\mathrm{a}}$ & $1.0 \pm 0.56^{\mathrm{c}}$ & $0.74 \pm 0.12^{b}$ & $0.55 \pm 0.06^{\mathrm{a}}$ & $0.62 \pm 0.17^{b}$ & 3.446 & 0.005 \\
\hline Eclipta & Stem & $2.15 \pm 1.21^{b}$ & $2.10 \pm 1.02^{\mathrm{b}}$ & $1.15 \pm 0.13^{\mathrm{a}}$ & $1.53 \pm 0.03^{\mathrm{a}}$ & $2.04 \pm 0.06^{b}$ & $1.27 \pm 0.18^{\mathrm{a}}$ & 17.06 & 0.000 \\
\hline prostrata $L$. & Root & $2.15 \pm 1.21^{\mathrm{b}}$ & $1.16 \pm 0.60^{\mathrm{a}}$ & $1.3 \pm 0.57^{\mathrm{a}}$ & $1.56 \pm 0.71^{\mathrm{a}}$ & $1.35 \pm 0.51^{\mathrm{a}}$ & $1.21 \pm 0.44^{\mathrm{a}}$ & 9.248 & 0.000 \\
\hline Woodfordia & Stem & $2.15 \pm 1.21^{\mathrm{b}}$ & $2.77 \pm 1.09^{c}$ & $1.27 \pm 1.17^{\mathrm{a}}$ & $2.02 \pm 1.15^{b}$ & $1.17 \pm 0.98^{\mathrm{a}}$ & $1.05 \pm 0.98^{\mathrm{a}}$ & 13.247 & 0.000 \\
\hline fructicosa Kurz. & Root & $2.15 \pm 1.21^{\mathrm{c}}$ & $1.28 \pm 0.49^{b}$ & $1.53 \pm 0.82^{b}$ & $0.65 \pm 0.39^{\mathrm{a}}$ & $0.92 \pm 0.19^{\mathrm{a}}$ & $1.33 \pm 0.39^{\mathrm{b}}$ & 6.531 & 0.000 \\
\hline
\end{tabular}

\section{CONCLUSION}

The present research suggests that the extracts of Ageratum conyzoids and Eclipta prostrata have showed higher allelopathic effects among all studied medicinal plants. From the present preliminary investigation, it can be concluded that all these plants exhibited remarkable negative allelopathic potential by significantly affecting the germination and hypocotyle and root growth of both Triticum aestivum and Pisum sativum.

The phytochemicals especially the phenolic compounds, alkaloids and saponins present in the plants under study responsible for allelopathy. So, the results revealed the presence of medicinally important constituents in the plants studied. Therefore, extracts from these plants could be seen as a good source for useful drugs. There was definite co-relation between traditional application of plants and possession of secondary metabolites, which supports the scientific basis for the traditional medicinal system. This result may be useful to future workers to select a group of plants having similar constituents to isolate biologically active principle or prepare remedies for particular case. 
Table 6: Effect of plant aqueous extracts on radicle length of pea. For each parameter, significant difference between mean among the treatments are indicated by different letters (Duncan homogeneity test, $\dot{a}=\mathbf{0 . 0 5}$ ). $\mathrm{F}$ and $\mathrm{P}$ values were obtained by one way analysis of variance (ANOVA). $(n=60)$.

\begin{tabular}{|c|c|c|c|c|c|c|c|c|c|}
\hline \multirow[b]{2}{*}{ Species name } & \multirow[b]{2}{*}{ Plant parts } & \multicolumn{6}{|c|}{ Radicle length $(\mathrm{cm})$ at different concentration } & \multirow[b]{2}{*}{ F-Value } & \multirow[b]{2}{*}{ P-Value } \\
\hline & & Control & $2 \%$ & $4 \%$ & $6 \%$ & $8 \%$ & 10 & & \\
\hline Ageratum & Stem & $3.40 \pm 1.71^{\mathrm{c}}$ & $1.75 \pm 0.97^{\mathrm{a}}$ & $1.8 \pm 1.10^{\mathrm{a}}$ & $2.37 \pm 1.30^{\mathrm{b}}$ & $1.52 \pm 0.24^{\mathrm{a}}$ & $2.27 \pm 0.09^{\mathrm{b}}$ & 6.85 & 0.000 \\
\hline conyzoides $L$. & Root & $3.40 \pm 1.71^{\mathrm{a}}$ & $2.87 \pm 0.55^{\mathrm{a}}$ & $2.80 \pm 0.98^{\mathrm{a}}$ & $2.67 \pm 1.43^{\mathrm{a}}$ & $2.94 \pm 0.37^{\mathrm{a}}$ & $2.89 \pm 1.00^{\mathrm{a}}$ & 1.38 & 0.230 \\
\hline Cannabis & Stem & $3.40 \pm 1 .^{b}$ & $2.01 \pm 1.22^{\mathrm{a}}$ & $2.52 \pm 1.55^{\mathrm{a}}$ & $2.46 \pm 1.6^{\mathrm{a}}$ & $2.06 \pm 1.13^{\mathrm{a}}$ & $2.35 \pm 1.43^{\mathrm{a}}$ & 1.02 & 0.404 \\
\hline sativa $L$ & Root & $3.40 \pm 1.3^{b}$ & $2.01 \pm 1.43^{\mathrm{a}}$ & $2.52 \pm 1.93^{\mathrm{a}}$ & $2.46 \pm 1.4^{\mathrm{a}}$ & $2.06 \pm 1.31^{\mathrm{a}}$ & $2.35 \pm 1.26^{\mathrm{a}}$ & 1.53 & 0.180 \\
\hline Eclipta & Stem & $3.40 \pm 1.71^{\mathrm{b}}$ & $5.36 \pm 2.15^{\mathrm{c}}$ & $2.86 \pm 1.08^{\mathrm{a}}$ & $3.26 \pm 1.34^{b}$ & $3.16 \pm 1.01^{\mathrm{b}}$ & $2.80 \pm 1.30^{\mathrm{a}}$ & 2.11 & 0.081 \\
\hline prostrata $L$. & Root & $3.40 \pm 1.71^{\mathrm{b}}$ & $3.33 \pm 1.66^{b}$ & $3.08 \pm 1.48^{b}$ & $2.59 \pm 1.24^{b}$ & $3.06 \pm 1.37^{b}$ & $2.33 \pm 0.89^{\mathrm{a}}$ & 3.05 & 0.011 \\
\hline Woodfordia & Stem & $3.40 \pm 1.71^{\mathrm{a}}$ & $7.58 \pm 2.14^{\mathrm{d}}$ & $7.29 \pm 2.83^{\mathrm{d}}$ & $6.46 \pm 2.9^{c}$ & $6.85 \pm 2.36^{\mathrm{c}}$ & $5.68 \pm 1.90^{\mathrm{b}}$ & 21.20 & 0.000 \\
\hline fructicosa Kurz. & Root & $3.40 \pm 1.71^{\mathrm{a}}$ & $6.84 \pm 0.77^{b}$ & $8.81 \pm 0.62^{\mathrm{c}}$ & $9.07 \pm 0.4^{\mathrm{d}}$ & $8.18 \pm 0.75^{\mathrm{c}}$ & $8.96 \pm 0.97^{c}$ & 34.87 & 0.000 \\
\hline
\end{tabular}

\section{Phytochemical screening}

Alkaloids, saponins, tannins, terpenoids, phenols, essential oils, glycosides and flavonoids were the phytochemicals present in the plants (Table 7). Phenolic compounds and saponin were present in higher amount in A. conyzoides. Essential oil was present in higher amount in root extracts of E. prostrata. Alkaloid and flavonoid were present in higher amount in $W$. fructicosa whereas tannin was in higher amount in C. sativa (Tables 7 and 8).

Table 7 :Phytochemical constituents of selected medicinal plants studied.

\begin{tabular}{|c|c|c|c|c|c|c|c|c|c|}
\hline \multirow{2}{*}{$\begin{array}{l}\text { Name of } \\
\text { the species }\end{array}$} & \multirow{2}{*}{$\begin{array}{l}\text { Plant } \\
\text { parts }\end{array}$} & \multicolumn{8}{|c|}{ Phytochemical constituents } \\
\hline & & Alkaloids & Flavonoids & Tannins & Terpenoids & Glycosides & Saponins & Phenols & Essential oils \\
\hline Ageratum & Stem & ++ & ++ & - & ++ & - & ++ & +++ & ++ \\
\hline conyzoides & Root & ++ & + & - & + & - & ++ & ++ & ++ \\
\hline Cannabis & Stem & + & + & ++ & ++ & - & ++ & +++ & + \\
\hline sativa & Root & + & + & - & - & - & ++ & ++ & ++ \\
\hline Eclipta & Stem & + & ++ & +++ & ++ & + & +++ & + & ++ \\
\hline prostrata & Root & + & ++ & + & + & + & - & +++ & ++ \\
\hline Woodfordia & Stem & +++ & +++ & ++ & ++ & + & - & ++ & + \\
\hline fructicosa & Root & + & +++ & ++ & ++ & + & - & +++ & ++ \\
\hline
\end{tabular}

If PPT is slight ' +', Medium ' ++ ', Heavy ' +++ ', Not detected' -'.

Table 8: Quantitative crude estimation of phytochemicals present in the plants studied.

\begin{tabular}{|c|c|c|c|c|c|c|c|c|}
\hline \multirow[b]{2}{*}{ S.N. } & \multirow[b]{2}{*}{ Name of the species } & \multirow[b]{2}{*}{ Plant part } & \multicolumn{6}{|c|}{ Crude estimated amount of phytochemicals } \\
\hline & & & Alkaloid (\%) & Flavonoid (\%) & Saponin (\%) & Tannin $(\%)$ & Phenol (\%) & Essential oil (\%) \\
\hline \multirow[t]{2}{*}{1} & Ageratum & Stem & 4.64 & 5.4 & 14.58 & - & 11.31 & 2.6 \\
\hline & conyzoides & Root & 6.12 & 2.6 & 12.14 & - & 3.33 & 5.3 \\
\hline \multirow[t]{2}{*}{2} & Cannabis & Stem & 4.12 & 7.12 & - & 4.04 & 2.17 & 2.15 \\
\hline & sativa & Root & 5.92 & 8.18 & - & 0.95 & 10.87 & 1.8 \\
\hline \multirow[t]{2}{*}{3} & Eclipta & Stem & 4.36 & 3.78 & 15.38 & 2.3 & 9.57 & 0.3 \\
\hline & prostrata & Root & 3.12 & 3.2 & 12.54 & - & 3.32 & 7.4 \\
\hline \multirow[t]{2}{*}{4} & Woodfordia & Stem & 10.36 & 13.42 & - & 2.6 & 4.57 & 0.45 \\
\hline & fructicosa & Root & 3.04 & 16.16 & - & 2.9 & 10.17 & 3.9 \\
\hline
\end{tabular}

'-'not detected.

\section{ACKNOWLEDGEMENT}

We are thankful to Nepal Academy of Science and Technology, for providing financial support for this research work.

\section{REFERENCES}

1. Koche, D., Rupali, S., Syed, I. and Bhadange, D.G. 2010. Phytochemical screening of eight traditionally used ethnomedicinal plants from Akola district (MS) India. International Journal of Pharmacology and Biological Sciences.1(4): 253-256. 
2. Edeoga, H.O., Okwu, D.E. and Mbaebie, B.O. 2005.Phytochemical constituents of some Nigerian medicinal plants. African Journal of Biotechnology. 5(4):357-361.

3. Rice, E.L .1984. Allelopathy. Second edition. Academic Press Inc. Orlando Florida,USA.422.

4. Molisch, H .1937. Der einflusseinerpflanze auf die andere Allelopathie Jena . Germany, Gustav Fischer.

5. Shao-Lin, P., Jun, W. and Qin-Feng, G. 2004. Mechanism and active variety of allelochemicals; A review. Acta Botanica Sinica. 46 (7): 757-766.

6. Maharjan, S., Shrestha, B.B. and Jha, P.K. 2007. Allelopathic effcts of aqueous extracts of leaves of Partheniumhysterophorus L. on seed germination and seedling growth of some cultivated and wild herbaceous species. Scientific World. 5(5): 85-95.

7. Gyawali, R., Jnawali, D. and Kim, K.S. 2008. Phytochemical screening of some species of Nepalese medicinal plants. In Medicinal Plants in Nepal: An anthology of contemporary research. 43-49. Eds. PK Jh a, SB Karmacharya, MK Chettri, CB Thapa and BB Shrestha. Ecological Society (ECOS), Kathmandu, Nepal.

8. Compton, W.M., Tulshi, D., Saha, P., Conway, K. and Grant, B.F. 2009. The role of Cannabis sativa use within a dimensional approach to Cannabis sativa use disorders. Drug Alcohol Dependence Journal. 100: 221-227.

9. Sofowora, A. 1993. Medicinal plants and traditional medicine in Africa. Spectrum Books Ltd., Ibadan, Nigeria. 191-289.

10. Trease, G.E. and Evans, W.C. 1989. Pharmacognsy. $11^{\text {th }}$ edn. BraillianTiridel Can. Macmillian publishers.

11. Harborne, J.B . 1973. Phytochemical Methods. Chapman and Hall, London. 113.

12. Muscolo, A., Panuccio, M.R. and Sidari, M. 2001. The effect of phenols on respiratory enzymes in seed germination respiratory enzyme activities during germination of Pinuslaricio seeds treated with phenols. Plant Growth Regulators.35: 31-35.

13. Olofsdotter, M. 2001. Rice - A step toward use of Allelopathy. Agronomy Journal. 93: 3-8.

14. Umer, A., Yousaf, Z., Khan, F., Hussain, U., Anjum, A., Nayyab, Q. and Younas, A. 2010. Evaluation of allelopathic potential of some selected medicinal species. African Journal of Biotechnology. 9(37) : 6194-6206.

15. Nishida, N., Tamotsu, S., Nagata N., Saito, C. and Sakai, A. 2005. Allelopathic effects of volatile monoterpinoides produced by Salvia leucophylla: Inhibition of cell proliferation and DNA synthesis in the root apical meristem of Brassica campestris seedlings. Journal of Chemical Ecology; 31: 1187-1203.

16. Bhowmik, P.C. and Doll, J.D. 1984. Allelopathic effects of annual weeds residues on growth and nutrient uptake of corn and soyabeans. Agronomic Journal.76: 383-388.

17. Qasem, J.R. 1993. Allelopathic effect of some common weeds on growth of wheat and barley. Dirasat. Series B. Pure and Applied Sciences .20(2): 5-28.

18. Singh, R., Singh, S., Kumar, S. and Arora, S. 2007. Evaluation of anti-oxidant potential of ethyl acetate extract of Acacia auriculiformis A. Cunn. Food Chemistry and Toxicology .45: 1216-1223.

19. Han, C.M., Pan, K.W., Wu, N., Wang, J.C. and Li, W. 2008 . Allelopathic effect of ginger on seed germination and seedling growth of soybean and chive. Science Horticulture.116(3): 330336 .

20. Li, H.Y., Pan, K.W., Liu, Q. and Wang, J.C. 2009. Effect of enhanced ultraviolet-B on allelopathic potential of Zanthoxylum bungeanum. Science Horticulture. 119 (3): 310-314. 